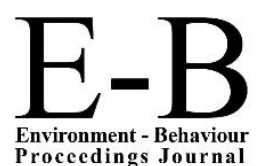

Environment - Behaviour
Proceedings Journal

\section{AIVCE-BS-1, 2020ShahAlam}

https://www.amerabra.org; https://fspu.uitm.edu.my/cebs; https://www.emasemasresources.com/ AMEABRA International Virtual Conference on Environment-Bahaviour Studies, ${ }^{\text {st }}$ Series cE-Bs, FSPU, Universiti Teknologi MARA, Shah Alam, 24-25 Jun 2020

\section{e-IPH}

- International Publishing House Ltd United Kingdom

\title{
Confronting Mental Disorder in Urban Physical Setting
}

\author{
Marlyana Azyyati Marzukhi ${ }^{1}$, Nur Masyitah Ghazali ${ }^{2}$, Oliver Ling Hoon Leh¹, Na'asah Nasrudin'1 \\ 1 Centre of Studies for Town and Regional Planning, Faculty of Architecture, Planning \& Surveying, \\ Universiti Teknologi MARA, Puncak Alam,Malaysia. \\ 2Centre of Graduate Studies, Faculty of Architecture, Planning \& Surveying, \\ Universiti Teknologi MARA, Shah Alam,Malaysia.
}

marlyana@uitm.edu.my, masyitah.ghazali@gmail.com, oliver3979@uitm.edu.my, naasa717@uitm.edu.my

Tel: +60133953379

\begin{abstract}
Mental health issues have many causes, and this includes the changing and unpredictable elements of the urban physical setting. Thus,this research is crucial to understand the mental health challenges of the urban population in Malaysia. Therefore,the objective of this research is to assess the magnitude of mental health outcomes and associated factors of the urban physical setting among the urban population.A study was carried out at two low-cost flats in Lembah Pantai,Kuala Lumpur,with a sample size of 102 respondents. The findings show that there is a correlation between urban physical environment settings, particularly green spaces with mental disorders (depression, anxiety, and stress).
\end{abstract}

Keywords: urban planning; environment; mental; health

eISSN: 2398-4287@ 2020. The Authors. Published for AMER ABRA cE-Bs by e-International Publishing House, Ltd., UK. This is an open access article under the CC BYNC-ND license (http://creativecommons.org/licenses/by-nc-nd/4.0). Peer-review under responsibility of AMER (Association of Malaysian Environment-Behaviour Researchers), ABRA (Association of Behavioural Researchers on Asians) and cE-Bs (Centre for Environment-Behaviour Studies), Faculty of Architecture, Planning \& Surveying, Universiti Teknologi MARA, Malaysia.

DOI: https://doi.org/10.21834/ebpj.v5i14.2180

\subsection{Introduction}

It is important to note that mental health issues have many causes, in many cases, this includes the changing and unpredictable elements of the urban physical setting. Understanding how the urban physical setting influences mental health is central as "health extends far beyond medical care" (Schema, 2018). By 2020, mental health problems will rank as the second biggest health problem in Malaysia after heart disease (Lee \& Lai, 2017). However, there is a lack of research to understand how the urban physical setting can influence mental health. Understanding of this relationship is critical as all the consequences-reflected in anxiety, stress, and depression-are impacting people in different ways. Thus, the objectives of this research are to assess the magnitude of mental health outcomes and associated factors of urban physical settings among the urban population. As Bovell-Ammon et al. (2020) claimed, "home is where the health is, both physically and mentally.

In this context, the people's health is the foundation for sustainable development that is informed by research evidence from disciplines such as urban planning and public health that are well-positioned to consolidate the realisation of the ambition of New Urban Agenda. The New Urban Agenda adopted at the Habitat III cities conference in Quito in October 2016 has indicated the improvement of human health and well-being as a key priority to achieve sustainable development goals. In this context, the people's health is the foundation for sustainable development that is informed by research evidence from disciplines such as urban planning and public health that are well-positioned to consolidate the realisation of the ambition of this New Urban Agenda. The urban physical setting is an essential element in urban planning to control development in the urban area. The urban physical setting is a framework that using space as a critical resource to transform a city vision to reality for development and engaging stakeholders along the way (UN Habitat, 2013). Thus, urban physical setting, particularly the green space, is an essential element for spatial planning in urban areas to create a sustainable environment for living, work, and play. As green is a part of the urban physical environment, higher availability green spaces can be

eISSN: 2398-4287@ 2020. The Authors. Published for AMER ABRA cE-Bs by e-International Publishing House, Ltd., UK. This is an open access article under the CC BYNC-ND license (http://creativecommons.org/licenses/by-nc-nd/4.0/). Peer-review under responsibility of AMER (Association of Malaysian Environment-Behaviour Researchers), ABRA (Association of Behavioural Researchers on Asians) and cE-Bs (Centre for Environment-Behaviour Studies), Faculty of Architecture, Planning \& Surveying, Universiti Teknologi MARA, Malaysia.

DOI: https://doi.org/10.21834/ebpj.v5i14.2180 
important factors that moderate the relationship between stressful life events and health and reinforce the feeling of happiness and life satisfaction (D'Alessandro et al., 2015).

Green spaces, plaza, or squares make a city alive and give more social interaction directly and indirectly that are needed to drive a new foundation for health. The association between mental health well-being depends on the type of green spaces, distance, and accessibility, quality of green spaces, and time spent in green areas (Houlden, 2017, Hassen 2016, Van den Berg et al., 2017). The function of green spaces such as parks, neighbourhood park, playgrounds, nature parks, and others is for physical activities, whether active or passive recreational activities. Green space is a place for people to recover from fatigue and stress after long hours of works. The number of provisions, location, and accessibility is essential for urban dwellers, especially for public parks. Therefore, understanding how the urban physical setting, particularly green spaces, influences mental health is central as "you cannot separate your health from where you live" (Sandel, 2020).

Despite the importance of understanding the supportive role of the urban physical setting in improving mental health, the interrelationships between both are somehow limited (Douglas et al., 2017). It is plausible that these fields influence each other over time, and understanding this sequencing is vital for understanding their relationships. Numerous works of literature have investigated the relationship between characteristics of the urban physical environment and physical health; however, little is known about the effects of urban physical setting on the mental health of the urban population (Gruebner et al., 2017; Marzukhi, 2020a). Therefore, this research is important to meet the crucial aspect of planning and health challenges of the urban population, which will cause a transformative effect on the lives of the community.

\subsection{Literature Review}

According to Sarkar and Webster (2017), the key attributes of a built environment related to density, land use mix, design, and accessibility to specific destinations, access to urban green space. A study by Qiu et al. (2019), has found that urban physical environments are significant factors that increased the risk of urban dwellers to have lowest mental health well-being. Helbich's (2018) phrase "the environmental context affects people's mental health", informs the idea that the environment can also present devastating consequences for people's mental well-being. It is plausible that these fields influence each other over time, and understanding this sequencing is vital for understanding their relationships (Marzukhi, 2020b). It is also supported by research conducted by Wolch (2014) where he stated that green spaces are essential as it is a place for physical activities, and it is vital to mental health.

\subsection{Mental Disorder}

According to WHO (2018), mental health is a state of well-being in which individual realises their abilities, can cope with the normal stresses of life, can work productively and can make a contribution to their community. Mental health is an individual's ability to think, interacting with communities, and earn for living. Mental disorder referred to a wide range of mental health conditions where it affects an individual's mood, thinking, and behaviour. Mental health becomes a mental illness when ongoing signs and symptoms cause constant stress and affect an individual's ability to function (Mayo,n.d.). According to Steel et al. (2014), "one out of five adults suffered from a mental disorder within the past year." What is worse, one in every five people is depressed, two in every five are anxious, and one in every ten people is having stress problems in Malaysia (National Health and Morbidity Survey, 2017). Three types of common mental disorder which is anxiety, depression, and stress will emphasise for this research.

Butler (1993) defines stress as a dynamic process reflecting internal and external factors of individuals, which is the characteristics and their circumstances, and their interaction. For the definition of depression, according to the World Health Organisation (n.d), it is a persistent sadness, lack of interest in previously enjoyable activities disturb sleep, appetite, tiredness, and poor concentration. Depression is a common illness that affects one's mood and behaviour. Meanwhile, the definition of anxiety is feelings of worry, nervousness, fear, and apprehension that also can be accompanied by physical symptoms such as the increase of blood pressure and nausea (Mental Health Handbook, 2019). In current years, an increasing number of psychiatric disorders problems in Malaysia, as stated in National Health and Morbidity Survey 2017, 29\% of Malaysians had depression and anxiety disorder compared to $12 \%$ in 2011.

\subsection{Green Space}

Furthermore, the focus on the urban physical setting is explained by the fact that there is a growing need to prioritise green connectivity (WHO, 2018). A study by James et al. (2015) indicates that green connectivity and better walkability was associated with less depression of the urban population. However, Gruebner et al. (2017) claim that "[a]though studies have looked into different mental health outcomes, they have not been systematically assessed within the same contexts, that is, whether, e.g., green spaces are associated with similar effects across mental health dimensions." This is particularly important as the New Urban Agenda adopted has indicated that a minimum of $15 \%$ of urban space should be dedicated to open, green and quality space. The number of provisions, location, and accessibility is essential for urban dwellers, especially for public parks. The depressive mood can be prevented by providing adequate green spaces to become a buffer for noise and air pollution for different sources (Rautio et al., 2017). These factors can increase the risk of individuals associated with mental health problems, whether directly or indirectly affect.

American Psychiatric Association (2016) one area of substantial research is the benefit of natural environment or green space which can help people to recover from the mental fatigue of work. Serafini (2014) space becomes a place the nature, buildings, landscape, and forms in spaces have a meaningful interaction with life. A high level of accessibility to physical activity is critical because good physical health can create a healthy mind. Sturm and Cohen (2014) stated that the distance of residential and parks significantly related to mental health, and Rao et al. (2007) claimed that access to green open spaces could increase physical activity and mental well-being. 
In this sense, there is a positive relationship between walkability and mental health well-being by physical activities which when the higher walkable design, access to green spaces for physical activities is convenient, and it has positive consequences on mental health. Liu et al. (2017) suggested that people who engage in physical activities and interact with nature can improve mental health.

\subsection{Methodology}

The area selected for the case study is two low-cost flat, PPR Pantai Ria and PPR Kerinchi Lembah Pantai in the Federal Territory of Kuala Lumpur within the administrative boundary of Kuala Lumpur City Hall (DBKL). The total area of Pantai Ria low-cost flats is 9.41 acres, and the total area of Kerinchi Lembah Pantai low-cost flats is 11.12 acres. The character of each selected area consists of highdensity housing, the provision of green spaces in the housing scheme, the distance to public open spaces, and facilities provided in the housing scheme and surroundings. PPR Pantai Ria low-cost flats are located near to Pantai Dalam commuter station, whereas PPR Kerinchi Lembah Pantai low-cost flats are located near to Pantai Hillpark which can access with New Pantai Expressway (NPE).

\subsection{Questionnaire Survey and Sampling of Respondents}

The DASS-21 is the shorter version of the 42-item Depression Anxiety Stress Scale (DASS-42), which was originally developed by Lovibond et al. (1995). The DASS- 21 item is a set of three self-report scales designed to measure the negative emotional states of depression, anxiety, and stress. In this research, the questionnaire emphasises on identifying the public opinion on the attributes of urban physical setting to mental health, which is green space, and a checklist of adaptation on Depression Anxiety Stress Scales (DASS21).

A total of 102 respondents were selected from the total population of 17,388 in the study area by using Raosoft Sample Size Calculator. The samples were determined with the confidence intervals of 92 per cent based on their urban's profile. Each of the three DASS scales contains seven items. Each item is rated on a four-point Likert scale of frequency or severity of the participants' experiences. The respondents were asked to indicate their assessment to measure the emotional states of depression, anxiety, and stress, ranging from 'did not apply to me at all' (1) until 'applied to me very much or most of the time' (4). The samples covered both male and female, different ethnic groups, and different age groups. Types of sampling used are stratified random sampling for the respondent's selection and purposive sampling for the study area selection because it is the most suitable for the research. This method is ideal because this research will consist of a questionnaire survey to the participant who may experience mental disorder problems or without a mental disorder problem. The participant will be chosen randomly, which will represent the total population of the areas. Data analysis for this research is based on a questionnaire and checklist of adaptation on Depression Anxiety Stress Scales (DASS-21) by using the IBM SPSS software.

\subsection{Findings and Discussion}

The results of states of depression, anxiety, and stress are self-reported scales using DASS-21. From the DASS-21 score, the severity states of depression, anxiety, and stress are calculated. The results also show the number of respondents having depression, anxiety, and stress as general. By carefully examining the data, data are generated for each respondent on the form of mental health problems, as shown in Table 1.

Table 1. Each respondent state of mental health by DASS-21 Score

\begin{tabular}{lll}
\hline Types of Mental Health Problem & Nos & $\%$ \\
\hline Normal & 39 & 38.2 \\
Depression & 6 & 5.9 \\
Anxiety & 10 & 9.8 \\
Stress & 10 & 9.8 \\
Depression \& Anxiety & 3 & 2.9 \\
Depression \& Stress & 2 & 2.0 \\
Anxiety \& Stress & 7 & 6.9 \\
Depression, Anxiety \& Stress & 25 & 24.5 \\
Total & 102 & 100.0 \\
\hline
\end{tabular}

Table 1 shows that 39 respondents are not having any mental health problems and at a normal state, which is $38.2 \%$. However, there are 25 respondents $(24.5 \%)$ that having depression anxiety and stress at the same time. The severity level of the mental health problems is varying, and from this data, it is clearly shown that most of the respondents are having either having one type or more than one mental health problem.

Green spaces or public spaces are important for social activities, physical activities and to restore from fatigue and stress, especially in the natural environment. It is a place other than home that most people will visit for recreational activities. Good and vibrant green spaces or public spaces will attract people to spend their time. Based on the result in Table 2,50\% of the respondents find that it is easy to wind down at green spaces at a good part of their time. 33.3\% of the respondents feel easy to wind down at green spaces at most of their time. The mean score for the feeling easily to wind down at green spaces is 3.11 . From the result also, it is shown that only $5.9 \%$ of the respondents do not agree with the statement. This shows that the respondents are feeling calm and easy to wind down when they at green spaces. Furthermore, a total of 35 respondents (34.3\%) are worried about the situation that can cause panic in public spaces at some of their time. The total of 40 respondents (39.2\%) does not have the feeling of the worries of situation that can cause panic in public spaces and having no problem of going to public spaces with a mean score 1.89 . there are 25 respondents, which is $24.5 \%$, 
worried about the situation that can cause panic in public spaces at a good part of their time and 2 respondents, which is $2 \%$ at most of their time. Other than this factor, it may due to respondents feeling unsafe at public spaces. Table 2 shows that 66 respondents who are $64.7 \%$ are feeling safe when they are at public spaces with a median score of 1.45 . However, 26 respondents (25.5\%) do not feel safe when they are at public spaces for some of their time and 10 respondents, which is $9.8 \%$ feeling the same at a good part of their time. These two factors show that the respondents may have anxiety. A person with anxiety will avoid things or events that can cause them to become panic.

Table 2. The respondents' action and feeling in green and public spaces

\begin{tabular}{|c|c|c|c|c|c|c|}
\hline Justification & & 1 & 2 & 3 & 4 & Total \\
\hline \multirow{3}{*}{$\begin{array}{l}\text { Easily to wind down when } \\
\text { at green spaces }\end{array}$} & Total & 6 & 11 & 51 & 34 & 102 \\
\hline & $\%$ & 5.9 & 10.8 & 50.0 & 33.3 & 100.0 \\
\hline & Mean & 3.11 & & & & \\
\hline \multirow{3}{*}{$\begin{array}{l}\text { Tend to over-react to a } \\
\text { situation when in public } \\
\text { spaces }\end{array}$} & Total & 57 & 33 & 8 & 4 & 102 \\
\hline & $\%$ & 55.9 & 32.4 & 7.8 & 3.9 & 100.0 \\
\hline & Mean & 1.60 & & & & \\
\hline \multirow{3}{*}{$\begin{array}{l}\text { Worried of situation that } \\
\text { can cause panic in public } \\
\text { spaces }\end{array}$} & Total & 40 & 35 & 25 & 2 & 102 \\
\hline & $\%$ & 39.2 & 34.3 & 24.5 & 2.0 & 100.0 \\
\hline & Mean & 1.89 & & & & \\
\hline \multirow{3}{*}{$\begin{array}{l}\text { Not feeling safe when at } \\
\text { public spaces }\end{array}$} & Total & 66 & 26 & 10 & 0 & 102 \\
\hline & $\%$ & 64.7 & 25.5 & 9.8 & 0 & 100.0 \\
\hline & Mean & 1.45 & & & & \\
\hline
\end{tabular}

The poor maintenance of provided green spaces within the residential areas also becomes one of the factors the residents avoid going for activities and socialising within their residential area. The nearest public park was located around 1 kilometre from both the study area and accessible by foot in 13 minutes of walk.

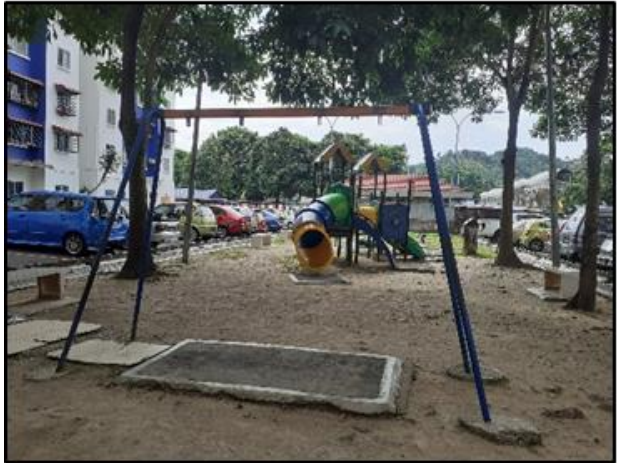

(a)

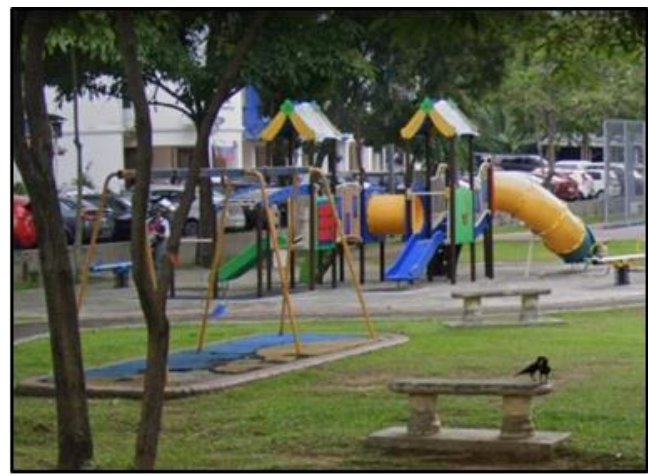

(b)

Fig. 1: Fig. 1. (a) Playground at PPR Pantai Ria is being vandalized; (b) Playground at PPR Kerinchi Lembah Pantai is not well maintained (Source: Author, 2020)

A correlation test had carried out to find the relationship between respondents' feelings when at public spaces and the symptoms of depression, anxiety, and stress (Table 3). The analysis showed a positive and significant correlation between respondents' feeling and the symptoms of common mental disorders which might be the reason a person with common mental disorders are avoiding being at public spaces.

\begin{tabular}{|c|c|c|c|c|}
\hline Justification & & Depression & Anxiety & Stress \\
\hline Tend to over-react to a situation & Coefficient (r) & $.328^{\star \star}$ & $.344^{* *}$ & $.513^{\star *}$ \\
\hline when in public spaces & Significant $(p)$ value & .001 & .000 & .000 \\
\hline Worried of situation that can cause & Coefficient (r) & $.357^{* *}$ & $.528^{\star *}$ & $.420^{* *}$ \\
\hline panic in public spaces & Significant $(p)$ value & .000 & .000 & .000 \\
\hline Not feeling safe when at public & Coefficient (r) & $.405^{\star \star}$ & $.492^{\star \star}$ & $.350^{\star *}$ \\
\hline spaces & Significant $(p)$ value & .000 & .000 & .000 \\
\hline
\end{tabular}

The results for respondents' feelings to rend to over-react when there was a situation that happened in public spaces shows positive and significant at 0.01 level to depression, anxiety, and stress. However, it has a strong correlation with stress symptoms, while the medium correlation with depression and anxiety, as shown in table 3. Besides, a correlation test of respondents' feelings of worried about a situation in public spaces that might cause panic to them has a positive and significant relationship. It has a strong correlation 
with anxiety symptoms, where they will be trying to avoid a situation that can cause a panic attack to them, especially in public and crowded spaces. In this sense, people with mental disorders will avoid being in public spaces as they worried that if a situation occurs and they might get panic and overreact to the situation and prefer to stay in their personal space such as at home.

Analysis of the correlation test on the respondents' feeling safe at public spaces also has a positive and significant relationship at level 0.01. respondents' do not feel safe in public spaces, which also becomes the reason they are avoiding being in public spaces. However, the respondents' agreed that being in green spaces, which refers to the natural environment, can make them easier to wind down.

\subsection{Conclusion}

In conclusion, green and public space contributes to mental disorders. Most of the respondents feeling that they are easy to wind down in a green area. However, the provided recreational activities within their residential area are not well maintained and lacking in provision. In addition, the crowding of vehicles at the ground level and parking spaces surrounding the provided recreational spaces also cause them to avoid going to provided recreational spaces. They will need to travel to find a proper green and public space. Thus, many factors could be the causal and contributing factors, and it is also related to an individual feeling and adaptation to the environment. A person who could not adapt to their surrounding may be affected by its and caused mental disorders when it could be controlled. The places and spaces for recreational and activities are important for social support and networking to create a sense of belonging to a person. The research findings can be applied by government agencies, professionals, and private sectors to plan a healthier urban physical environment. This research will add to the growing literature that suggests the importance of the built environment in shaping mental health.

\section{Acknowledgements}

The authors would like to express our gratitude to the Faculty of Architecture, Planning and Surveying, Universiti Teknologi MARA (UiTM), and Ministry of Higher Education Malaysia through Fundamental Research Grant Scheme (600-IRMI/FRGS 5/3 (063/2019) for their generous contribution towards this research.

\section{References}

American Psychiatric Association. (2016, September 12). Can Urban Environments Be Designed for Better Mental Health. Retrieved May 10, 2019, from American Psychiatric Association: https://www.psychiatry.org/news-room/apa-blogs/apa-blog/2016/09/can-urban-environments-be-designed-for-better-mental-health

Bovell-Ammon, A., Sandel, M. \& James, T. (2020). Housing As A Prescription For Health, Now And In The Future. https://www.healthaffairs.org/do/10.1377/hblog20200420.92256/full/

Butler, G. (1993). Definitions of stress. Occas Pap R Coll Gen Pract 61, 1-5.

D'Alessandro, D., Buffoli, M., Capasso, L., Fara, G.M., Rebecchi, A., \& Capolongo, S. (2015). Green areas and public health: improving well-being and physical activity in the urban context. Epidemiol Prev, 39(4), 8-13, 2015.

Douglas, O., Lennon, M. \& Scott, M. (2017). Green space benefits for health and well-being: A life-course approach for urban planning, design and management. Cities, $66,53-62$

Gruebner, o., Rapp, M.A., Adli, M., et al. (2017). Cities and mental health. Dtsch. Arztebl. Int., 114(8), 121-127

UN Habitat. (2013). Urban Planning for City Leader. Kenya: UN Habitat.

Hassen, N. (2016). The Influence of Green Space on Mental Health \& Well-being: A Scoping Review of Reviews. Toronto: Wellesley Institute.

Helbich, M. (2018). Mental Health and Environmental Exposures: An Editorial. International Journal of Environmental Research and Public Health, 1-4.

Houlden, V., Weich, S., \& Jarvis, S. (2017). A cross-sectional analysis of green space prevalence and mental well-being in England. BMC Public Health 17(460), 1-9.

James, P., Banay, R.F., Hart, J.E. \& Laden, F. (2015). A Review of the Health Benefits of Greenness. Current Epidemiology Reports, 2(2),131-142.

Lee, M.F. \& Lai, C.S. (2017). Exploring Learners' Mental Health Profile: A study in Universiti Tun Hussein Onn Malaysia. https://iopscience.iop.org/article/10.1088/1757$899 X / 226 / 1 / 012194$.

Liu, H., Li, F., Li, J., \& Zhang, Y., "The relationships between urban parks, residents' physical activity, and mental health benefits: A case study from Beijing, China" Journal of Environmental Management, 190, 223-230, 2017.

Lovibond, P.F. \& Lovibond, S.H. (1995). The structure of negative emotional states: comparison of the Depression Anxiety Stress Scales (DASS) with the Beck Depression and Anxiety Inventories. Behaviour Research and Therapy.33(3),335-43.

Mayo Clinic. (n.d.). Symptoms and cause - Mayo Clinic. Retrieved May 25, 2019, from Mayo Clinic: https://www.mayoclinic.org/diseases-conditions/mentalillness/symptoms-causes/syc-20374968?p=1 
Marzukhi, M. A. et. al., (2020a). The Effects of Changes to the Urban Physical Environment on Mental Disorder: Development of a theoretical framework. Journal of ASIAN Behavioural Studies, 5(16), 35-47.

Marzukhi, M. A. et. al., (2020b). A Bidirectional Associations between Urban Physical Environment and Mental Health: A theoretical framework. Environment-Behaviour Proceedings Journal, 5(13), 167-173.

Malaysian Psychiatric Association. (2019). Mental Health Handbook. Kuala Lumpur: Malaysian Psychiatric Association.

Qiu, Y., Liu, Y., Liu, Y \& Li, Z. (2019). Exploring the Linkage between the Neighborhood Environment and Mental Health in Guangzhou, China. International Journal of Environmental Research and Public Health, 16 (3206), 1-15.

Rao, M., Prasad, S., Adshead, F., \& Tissera, H. (2007). The Built Environment and Health. The Lancet, 370, 1111-1113.

Rautio, N., Filatova, S., Lehtiniemi, H., \& Miettunen, J. (2017). Living environment and its relationship to depressive mood: A systematic review. International Journal of Social Psychiatry, 1-12.

Sandel, M. (2020) Confronting COVID-19: The Effects of COVID-19 on Multifamily and Affordable Housing. https://urbanland.uli.org/inside-uli/confronting-covid-19healthy-buildings-optimizing-mental-health/

Sarkar, C. \& Webster, C. (2017). Urban environments and human health: current trends and future directions. Current Opinion in Environmental Sustainability, $25,33-44$.

Schema (2018). Case Studies. United Nations University: Kuala Lumpur.

Serafini, S. (2014, July). Neuroergonomics, Urban Design, and Sociogenesis. Retrieved May 9, 2019, from Biourbanism: www.biourbanism.org/neuroergonomics-urbandesign-sociogenesis/

Sturm, R., \& Cohen, D. (2014). Proximity to Urban Parks and Mental Health. J Ment Health Policy Econ, 17(1), 19-24.

Steel, Z., Marnane, C. \& Iranpour, C. (2014). The global prevalence of common mental disorders: a systematic review and metaanalysis 1980-2013. Int. J. Epidemiol, 43:476-493 Sturm, R., \& Cohen, D. (2014). Proximity to Urban Parks and Mental Health. J Ment Health Policy Econ, 17(1), $19-24$.

The New Urban Agenda (2017). United Nations: Habitat III Secretariat.

Van den Berg, M., van Poppel, M., Smith, G., Triguero-Mas, M., Andrusaityte, S., van Kamp, I., et al. (2017). Does time spent on visits to green space mediate the associations between the level of residential greenness and mental health? Urban Forestry and Urban Greening, 1-29.

Wolch, J. R., Byrne, J., \& Newell, J. P. (2014). Urban green space, public health, and environmental justice: The challenge of making cities 'just green enough'. Landscape and Urban Planning 125, 234-244.

World Health Organization (2018). Health and Sustainable Development. http://www.who.int/sustainable-development/cities/en/. 